\title{
The genus Inonotus and its related species in India
}

\author{
Sharma JR ${ }^{1}$, Das $\mathrm{K}^{2}$ and Mishra $\mathrm{D}^{1}$ \\ ${ }^{1}$ Botanical Survey of India, NRC, Dehradun 248195, India, email: jrs010@ rediffmail.com \\ ${ }^{2}$ Botanical Survey of India, Cryptogamy Unit, Howrah 711103, India, email: daskanadbsi@gmail.com
}

Sharma JR, Das K, Mishra D 2013 - The genus Inonotus and its related species in India. Mycosphere 4(4), 809-818, Doi 10.5943/mycosphere/4/4/16

\begin{abstract}
The genus Inonotus is subdivided into genera Inocutis, Inonotus sens. str., Onnia and Pseudoinonotus. A key to these genera, based on studies of Indian material, is provided. A new species, Inonotus ryvardenii is proposed based on an unique set of characters like coarsely hispid pilear surface, absence of any setal organs and small, hyaline to pale yellowish spores. Six other species, Inocutis tamaricis, I. texanus, Inonotus juniperinus, I. obliquus, I. ochroporus and I. porrectus are reported new for India. All species are illustrated and described based on Indian material. A key to the Indian species for each genus is also provided.
\end{abstract}

Key words - Hymenochaetaceae - key - macrofungi - new species - taxonomy

\section{Introduction}

The genus Inonotus P. Karst. (Hymenochaetales Oberwinkler; Hymenochaetaceae Donk) was proposed in 1879 to accommodate polypores with a pileate habit and pigmented basidiospores. Later, Donk (1933) emended the genus to encompass all the species with pigmented basidiospores and brown context, the characters present in I. cuticularis (Bull.) P. Karst., the type species (Ryvarden 1991). However, the concept of the genus was enlarged to include species with a great variation with regard to habit of the basidiocarp, shape and colour of the basidiospores, type and pigmentation of the spore wall and presence or absence of setal elements. Characters like presence of brown fibrous context, xanthochroic reaction of basidiocarp with $\mathrm{KOH}$ and monomitic hyphal system with simple septate hyphae remained the distinguishing features of the genus (Pegler 1964, Gilbertson 1976, Gilbertson \& Ryvarden 1986, Ryvarden \& Gilbertson 1993, Sharma 1995). Gottlieb et al. (2002) provided the morphology, cultural characters and molecular analysis of Inonotus sens. lat. in Argentina while Ryvarden (2005) recently published a monograph on Inonotus sens. lat. which dealt with 101 species including 10 new species and 6 new combinations.

Numerous characters from morphology, anatomy, sexuality, nuclear behavior, pigmentation and ecology suggest that Inonotus is heterogeneous (Fiasson 1982, Fiasson \& Niemela 1984, Dai 1995a, 1995b, 1999, Fischer 1996). Smaller more homogeneous subgroups are evident within the genus and several attempts were undertaken to split Inonotus into smaller more natural genera. As a result, Inonotus comprised numerous generic notations namely Mucronoporus, Onnia, Flaviporellus, Mensularia, Xanthoporia, Inonotopsis, Inocutis and Pseudoinonotus.

Only recently sequence data from the nuclear encoded large subunits (nuc-Isu) rDNA together with traditional characters have been used to re-examine the classification and phylogenetic relationships of the Hymenochaetales (Fischer et al. 2001, Neimela et al. 2001, 
Wagner \& Fischer 2001, 2002, Wagner \& Ryvarden 2002). DNA data, together with characters from morphology and karyology, have demonstrated Inonotus sens. lat. as polyphyletic and subdivided into genera: Inonotus sens. str. (I. hispidus), Inocutis (I. rheades), Mensularia (M. radiata), Pseudoinonotus (P. dryadeus) and Inonotopsis (I. subiculosa).

The genus Mensularia, which is separated mainly on the basis of strongly cyanophilous spores is not accepted because the collections of Inonotus radiatus made and studied from different parts of India either are acyanophilous or show a weak reaction that is difficult to observe with cotton blue. The genus Inonotopsis has no representation in India. The genera Inonotus sens. str., Inocutis, Pseudoinonotus and Onnia are accepted for the species of the genus Inonotus sens. lat. on the basis of studies on fresh field collections from different parts of the country and material deposited in various Indian herbaria.

\section{Materials \& Methods}

The study is mainly based on material collected during the past 25 years and study on specimens lying in the herbaria at AHMA, AMH, BSD, CAL, HCIO, DD, CAL, HCIO, PAN and PUN. Colour, texture, taste and odour of the basidiocarp are mostly based on fresh material in the field. The studied specimens are deposited at the cryptogrammic section of BSI at Dehra Dun (BSD).

All the materials were examined using an Olympus CX 41 microscope fitted with a drawing tube. The measurements and drawings were made from slide preparations stained with cotton blue, Melzer's solution and 5\% KOH. The abbreviations used include: IKI- = negative in Melzer's solution, CB- $=$ acanophilous, $\mathrm{CB}+=$ cyanophilous. Colour terms follow Rayner (1970) and Petersen (1996). Herbarium names used are after Holmgren et al. 1990. The abbreviations of authors of scientific names follow the recent edition of authors of fungal names (available at:http//www.index fungorum.org/Names/Names.asp).

A full description of each species is given based on Indian material. Important microscopic characters of the new records to India are illustrated. Basidium length excludes the lengths of the sterigmata. For measuring the spores, an average of 25 spores were considered. $\mathrm{L}=$ mean spore length (arithmetic average of all spores), $\mathrm{W}=$ mean spore width (arithmetic average of all spores), $\mathrm{Q}=$ (variation in the $\mathrm{L} / \mathrm{W}$ ratios between the specimens studied and $n$ (number of spores measured from a given number of specimens).

\section{Taxonomy}

\section{Key to genera}

1. Spores hyaline; hymenial setae always present.........................................

1. Spores coloured; hymenial setae present or absent.........................................

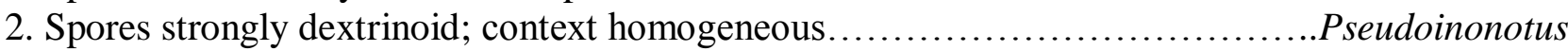

2. Spores indextrinoid; context duplex..........................................................

3. Basidiocarps with a granular core; hymenial setate absent............................ Inocutis

3. Basidiocarps without a granular core; hymenial setae present or absent...................Inonotus

Inocutis Fiasson \& Niemela, Karstenia 24(1): 24, 1984

Basidiocarps annual, pileate, upper surface yellowish to brown, hispid, glabrescent to rough; pore surface yellow to brown; context brown, corky, granular core present at base; hyphal system monomitic, generative hyphae simple septate, setal hyphae/setae absent; spores pigmented, thickwalled, smooth, IKI-, CB-, on hardwoods, causing a white rot.

The presence of a granular core at the base of context and absence of any setal organs and coloured spores are the features which separate this genus from the closely related Inonotus, Onnia, Mensularia and Inonotopsis.

Type species - Inocutis rheades (Pers.) Fiasson \& Niemela 


\section{Provisional key to the Indian species of Inocutis}

1. Pilear surface usually persistently hispid to woolly strigose; spores $5-6 \times 3.5-4 \mu \mathrm{m}$; on Populus..................................................................... rheades 1. Pilear surface hispid to tomentose, glabrous with age; spores longer than $7.5 \mu \mathrm{m}$; on other hosts. ... 2

2. Pilear surface becoming black and brittle with age or drying; on Tamarix.............. tamaricis

2. Pilear suface unchanging on drying or with age; on other hosts..............................

3. Pilear suface smooth and rusty brown with age; on oaks........................... dryophilus

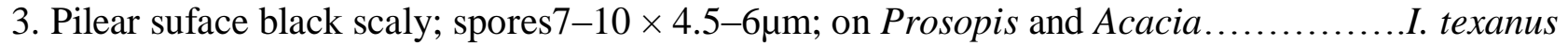

Inocutis tamaricis (Pat.) Fiasson \& Niemela, Karstenia 24(1): 25, 1984; Xanthochrous tamaricis Pat., Bull. Soc. Myc. France 20: 51, 1904 = Inonotus tamaricis (Pat.) Maire, Bull. Soc. Sci. natur. Maroc 14: 89, 1938

Figs $12-16$

Basidiocarps annual, solitary or sometimes in groups, soft when fresh, brittle on drying, 40$80 \mathrm{~mm}$ wide and broad, up to $20 \mathrm{~mm}$ thick at base; upper surface hispid to villose becoming glabrous and black and brittle with age or on drying, rusty to cinnamon brown; pore surface rusty brown becoming black with age, pores angular to lacerate, 1-3 per mm, tubes rusty brown, up to 20 mm deep; context zonate with alternating light and dark zones, with a distinct granular core of intermixed brown and whitish mycelium, with a thin layer of fibrous, yellowish brown tissue on the surface between the core and tube layer.

Hyphal system monomitic, hyphae of fibrous context mostly pale yellowish brown, thin to moderarly thick-walled, septate with rare branching; hyphae of granular core of two types: some dark brown, thick-walled, breaking into small fragments, 5-10 $\mu \mathrm{m}$ diam., others hyaline to pale yellow, thin-walled, simple-septate, some inflated and distorted, 3-12 $\mu \mathrm{m}$ diam.; tramal hyphae mostly pale yellowish, thin-walled simple septate with rare branching, 3-4 $\mu \mathrm{m}$ wide; hymenial setae absent; basidia narrowly clavate, 4-sterigmate; spores rusty brown to pale umber, thickwalled, ovoid to ellipsoid, IKI-, CB-, (5.6-)6-7.3(-7.7) $\times(3.8-) 4.5-6(-6.2) \mu \mathrm{m}, \mathrm{L}=6.81 \mu \mathrm{m}, \mathrm{W}=$ $5.27 \mu \mathrm{m}, \mathrm{Q}=1.25-1.36,(\mathrm{n}=25 / 1)$.

Specimens examined - INDIA, Tamil Nadu, Nilgiri, Burliar, on base of a Tamaricis tree, 7 Dec 2012, J.R. Sharma, JRS 1108 (BSD); ibid., Coimbatore, Annakutti, on base of a Tamaricis tree, 10 Dec 2012, J.R. Sharma, JRS 509 (BSD).

Remarks - This species grows on living or dead wood of Tamaricis in the plains. The host and the granular core are sufficient to recognize this species in the field. The species is related to $I$. rheades, but the later grows on Populus, has smaller spores and persistently hispid to strigose pilear surface. The granular core in the present species is quite small. I. tamaricis is confined to tropical areas.

Inocutis texanus (Murr.) Sed. Martinez, Mycotaxon 96: 3, 2006; Inonotus texanus Murr., Bull. Torrey Bot. Club 31: 597, 1904

Figs 19-24

Basidiocarps annual, sessile ungulate to applanate, up to $50 \mathrm{~mm}$ wide $80 \mathrm{~mm}$ broad and 40 $\mathrm{mm}$ thick near the base; upper surface tomentose to soft velutinate, soon becoming glabrous cracking radially and concentrically into angular scales, light to medium brown; pore surface yellowish brown when young becoming dark brown to blackish with age, pores circular to angular, 1-3 per $\mathrm{mm}$, dissepiments thick becoming lacerate with age, tube layer concolorous with the fibrous context, tubes 15-20 mm deep, brittle; context with a distinct granular core of intermixed white and brown tissue, fibrous context yellowish brown, usually up to $10 \mathrm{~mm}$ thick.

Hyphal system monomitic, generative hyphae pale yellowish brown, thin to moderately thickwalled, 4-7 $\mu \mathrm{m}$ wide, hyphae of granular core of two types: some dark brown, thick-walled, breaking into short fragments, $7-15 \mu \mathrm{m}$ diam., others hyaline to pale yellowish, thin to moderately thick-walled, simple-septate, some inflated and distorted 4-12 $\mu \mathrm{m}$ diam.; tramal hyphae mostly pale yellowish, thin -walled, simple septate, with rare branching, 3-5 $\mu \mathrm{m}$ wide; hymenial setae 
none; basidia clavate, 4-sterigmate, 16-22 $\times 5-6 \mu \mathrm{m}$; spores yellowish brown, thick-walled, ovoid to ellipsoid, IKI- ,CB-, (6.7-)7-10(-10.3) $\times(4.1-) 4.5-6(-6.2) \mu \mathrm{m}, \mathrm{L}=8.72 \mu \mathrm{m}, \mathrm{W}=5.32 \mu \mathrm{m}, \mathrm{Q}=$ $1.55-1.65,(\mathrm{n}=25 / 1)$.

Specimens examined - INDIA, Tamil Nadu, Coimbatore, Annakutti, on a fallen trunk of Acacia, 28 Nov. 2012, J.R. Sharma, JRS 1407 (BSD); ibid, Koller, on a dead standing trunk of Prosopis, 30 Nov. 2012, J.R. Sharma, JRS 1481 (BSD); ibid, Uttrakhand, Dehradun, Rajaji National Park, On dead trunk of Acacia, 21 Sept. 2011, J.R. Sharma, JRS 718 (BSD).

Remarks - This species has been repeatedly found growing on dead woods of Acacia and Prosopis. Inocutis texanus differs from closely related I. dryophilus in having larger basidiocarps, distinctive rimose scaly nature of upper surface and its host relationships.

Inonotus P. Karst., Meddn Soc. Faunna Flora fenn. 5: 39, 1879

Basidiocarps annual to rarely perennial, resupinate, effused-reflexed or pileate, sessile to rarely stipitate, solitary to imbricate, corky fleshy to woody hard and brittle on drying; pileus small to medium sized, dimidiate, applanate to conchate; upper surface glabrous, tomentose to hispid, yellowish to dark reddish brown, usually without a crust, hymenophore poroid; pore surface brown, pores 2-10 per $\mathrm{mm}$; context rusty to cinnamon brown, mycelial core absent; hyphal system monomitic, generative hyphae yellowish to brownish, simple septate; setal hyphae present or absent; hymenial or tramal setae present or absent; cystidia none; spores globose to ellipsoid, rarely cylindrical, smooth, hyaline to yellowish or brown; on dead and living hardwoods or coniferous woods, causing a white rot.

The genus is easy to recognize by its annual basidiocarps with a fibrous to soft or fragile consistency. The hyphae are monomitic and generally are wider than those of Phellinus which usually has woody, perennial basidiocarps with dimitic hyphal system.

Type species - Inonotus hispidus (Bull.: Fr.) P. Karst.

\section{Provisional key to the Indian species of Inonotus}

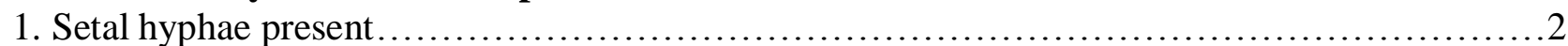

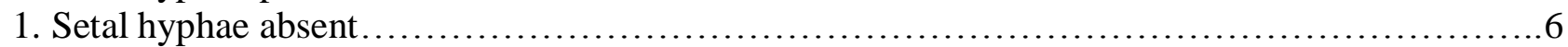

2. Ptychogastric anamorph with abundant chamydospores commonly produced................ rickii

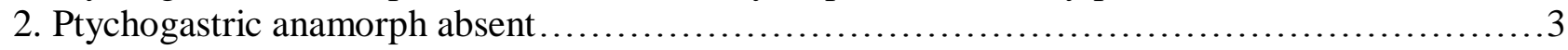

3. Branched setal hyphae present on pilear surface.................................. cuticularis

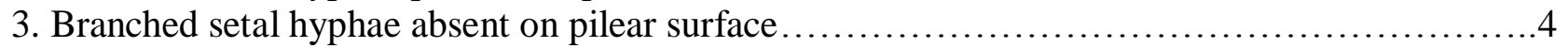

4. Setal hyphae present only in dissepiments................................... patouillardii

4. Setal hyphae present both in context and dissepiments.....................................5

5. Basidiocarps effused-reflexed to pileate; spores 5-7 $\times 4-5.5 \mu \mathrm{m}$; context not duplex.......................................................................... glomeratus

5. Basidiocarps applanate with a attenuated base; spores $7.5-9 \times 5.5-7 \mu \mathrm{m}$; context duplex................................................................. ochroporus

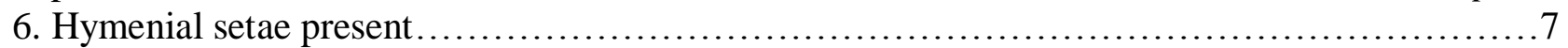

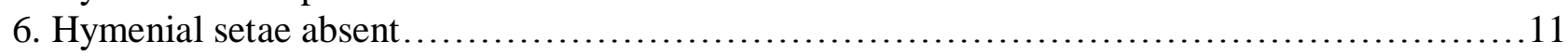

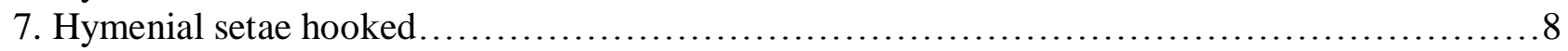

7. Hymenial setae straight ........................................................... 9

8. Pores 4-6 per mm; spores 5-7.5 $\times 4-5.5 \mu \mathrm{m}$; margin not bright yellow.............. hamusetulus

8. Pores 6-8 per mm; spores $4-4.5 \times 3.5 \mu \mathrm{m}$; margin bright yellow........................ radiatus

9. Basidiocarps resupinate; developing beneath bark or sapwood........................ obliquus

9. Basidiocarps sessile or effused-reflexed; not developing as above ........................ 10

10. Pilear surface strongly hispid and remaining more or less so at maturity; setae not with lateral

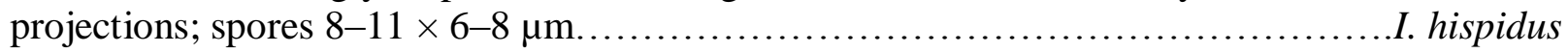

10. Pilear surface tomentose to glabrous at maturity, delimited on upper surface by a thin black crust; setae ventricose with lateral projections; spores 5.5-7.5 $\times 4.5-5.5 \mu \mathrm{m}$....I. diverticuloseta

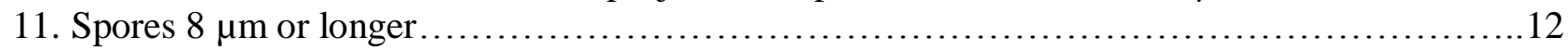




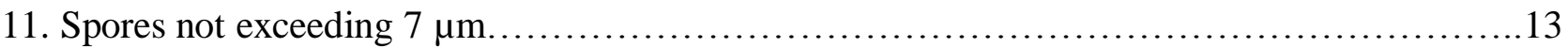

12. Pilear surface hispid turning black and brittle on drying or with age; spores $8-11 \times 6-8 \mu \mathrm{m}$; on oaks.

12. Pilear surface tomentose to glabrescent, unchanged on drying or with age; spores $7-8.9 \times 5-6.5$ $\mu \mathrm{m}$; on Tamarix.

I. subhispidus

13. Pilear surface coarsely hispid, forming a coarse hispid tomentum composed of fasciculated groups of agglutinated hyphae; spores hyaline to pale yellowish................... ryvardenii

13. Pilear surface not as above; spores dark brown to rusty brown .............................14

14. Pore surface and tubes oblique, appearing black and brittle at least in dried material; on roots of Juniperus........................................................ juniperinus

14. Pore surface and tubes not oblique, unchanged on drying or with age; pores 4-7 per mm; on other hosts.

15. Pilear surface multizonate; context bright ochraceous tawny; pores 5-7 per mm.....I. porrectus 15. Pilear surface azonate; context cinnamon brown; pores $4-5$ per $\mathrm{mm}$.

\section{I. tenuicarnis}

Inonotus juniperinus Murr., North Am. Fl. 9: 88, 1908

Figs 25, 26

Basidiocarps annual, pileate, sessile to dimidiate to flabelliform or substipitate, $30-70 \mathrm{~mm}$ wide and long, 5-10 mm thick, soft and flexible when fresh, brittle and rigid when dry; pilear surface rusty to umber brown, finely tomentose when young, becoming glabrous with age, radially rugulose with age, weakly zonate, slightly incrusted with age, margin acute, broadly sterile; pore surface deep rusty to umber brown, darkening on drying, pores angular, becoming dentate and irregular on drying, 3-5 per $\mathrm{mm}$, tubes concolorous, 5-7 $\mathrm{mm}$ deep, darkening and becoming oblique with age and drying; context rusty brown to umber brown, fibrous and fragile, zonate in well developed specimens, $4-8 \mathrm{~mm}$ thick.

Hyphal system monomitic, generative hyphae golden to rusty brown, thick-walled 3-6 $\mu \mathrm{m}$ wide; hymenial setae absent; basidia 10-20 × 4-7 $\mu \mathrm{m}$, spores rusty brown, slightly thick-walled, ellipsoid, IKI -, CB-, (4.7-)5-6.2(-5.9) $\times(3.7-) 4-5.3(-5.5) \mu \mathrm{m}, \mathrm{L}=5.75 \mu \mathrm{m}, \mathrm{W}=4.65 \mu \mathrm{m}, \mathrm{Q}=$ $1.20-1.28,(\mathrm{n}=25 / 2)$.

Specimens examined - INDIA, Sikkim, East Sikkim, Yongari, on the roots of Juniperus, 21 Sept. 1996, J.R. Sharma, JRS 1206 (BSD); ibid, Uttrakhand, Chamoli, Panwali, on roots of Juniperus, 13 Sept. 2008, J. R. Sharma, JRS 1307 (BSD).

Remarks - This species grows on roots of Juniperus at high altitudes. The oblique pore surface and tubes, blackening with age, absence of any setal elements and the host are the distinguishing features of this species.

Inonotus obliquus (Pers.: Fr.) Pilat, Atl. Champ. Eur. 1ll, p. 572, 1942; Boletus obliquus Pers., Syn. Fung., p. 548, 1801; Polyporus obliquus Pers.: Fr., Syst. Mycol., p. 378, $1821 \quad$ Figs 9-11

Basidiocarps annual, resupinate, becoming widely effused, developing only once beneath the bark or outer layers of wood on dead standing or fallen trees, eventually rupturing the bark, coriaceous fleshy in fresh specimens, hard and brittle on drying, consisting almost entirely of tubes running oblique to the substrate becoming easily separable, margin fertile; pore surface yellowish brown, becoming dark reddish brown, pores circular, 6-8 per $\mathrm{mm}$, dissepiments thick, entire, becoming thin and lacerate, tube layer dark reddish brown, brittle, 2-3 $\mathrm{mm}$ deep; context if present very thin, bright yellowish brown, faintly zonate corky, up to $3 \mathrm{~mm}$ thick; sterile conks black, hard and strongly cracked.

Hyphal system monomitic, generative hyphae dark brown, thin to moderately thick-walled, freely branched, 3-4 $\mu \mathrm{m}$ wide; basidia broadly clavate, $15-18 \times 9-11 \mu \mathrm{m}$; hymenial setae scattered, scarcely projecting or imbedded, subulate to ventricose, $15-25 \times 5-7 \mu \mathrm{m}$; basidiospores hyaline to pale brownish, ovoid to broadly ellipsoid, IKI-, CB-, (8.8-)9-10(-10.4) $\times(5.0-) 5.5-6.5(-6.8) \mu \mathrm{m}$, $\mathrm{L}=9.6 \mu \mathrm{m}, \mathrm{W}=6.10 \mu \mathrm{m}, \mathrm{Q}=1.53-1.64,(\mathrm{n}=25 / 2)$. 
Specimens examined - INDIA, Uttrakhand, Chamoli, Chirbasa, on a dead standing tree of Betula utilis, 10 Sept. 1998, J.R. Sharma, JRS 506 (BSD); ibid, Tehri, Virod, on a dead standing tree of Betula utilis, 12 Sept. 1993, J.R. Sharma, JRS 3012 (BSD)

Remarks - The wood attacked by I. oblquus is pierced through by dark lines and stained yellowish white. The habit of the fungus is so characteristic in appearance that it cannot be confused with any other species. After the basidiocarps emerge from under the bark, the fungus then dries up, cracks and breaks into pieces matching in colour with I. radiatus. The cracks in the wood are filled with mycelium and the pressure of the growing mycelium ultimately splits the wood into plates along the cracks. This species is found growing frequently on both the living and dead trees of Betula utilis near the tree line in the Himalayas. Inonotus obliquus produces conspicuous black sterile conks on the living trees, the fungus invades, kills and decays the sap wood weakening the tree which then finally dies and the next summer the basidiocarps develop once under the disrupted bark. The basidiocarps weather rapidly and are generally quickly eaten by insects, and are rare to find even in the stands where infected trees are numerous.

Inonotus ochroporus (Van der Byl) Pegler, Trans. Brit. Mycol. Soc. 47: 183, 1964; Polyporus ochroporus Van der Byl, S. Afr. J. Sci. 18: 269, 1922

Figs 6-8

Basidiocarps annual, pileate, broadly attached, solitary to imbricate, $100-150 \mathrm{~mm}$ broad, 120-170 mm wide and up to $20 \mathrm{~mm}$ thick, soft and spongy when fresh, hard and brittle on drying, pileus dimidiate to attenuated towards the base, convex; upper surface soft and pubescent when young, becoming hard and brittle with age, mostly with an agglutinated cuticle, sometimes concentrically zoned and partly radially stiate, light brown, fulvous to dark brown, margin thin to rather thick entire or slightly lobed; pore surface ochre yellow to dark brown sometimes with a rosy tint, pore angular to irregular, 2-5 per $\mathrm{mm}$, dissepiments thin, entire or dentate, tubes 2-6 mm deep, ochraceous-yellow; context up to $10 \mathrm{~mm}$ thick, duplex in young specimens, upper part soft and ochraceous to golden brown mostly separated from the lower part by a thin, often indistinct black zone, becoming more prominent with age and closer to the base of the basidiocarp, lower part shiny, radially fibrous and hard, dark cinnamon brown.

Hyphal system monomitic, generative hyphae hyaline to rusty brown, branched, 2-6 $\mu \mathrm{m}$ wide; setal hyphae prominent in the dissepiments, rather rare and often difficult to find in the upper part of the context, mostly confined to the basal part of the pileus, acute thick-walled, 10-18 $\mu \mathrm{m}$ wide and up to $300 \mu \mathrm{m}$ long, mostly embedded, but also obliquely projecting into the hymenium, rarely forked in the upper part, hymenial setae apparently absent but in some collections they are found from rare to common, acute, subventricose, thick-walled dark brown, 12-25 × 6-9 $\mu \mathrm{m}$; basidia broadly clavate, 4-sterigmate $15-18 \times 6-10 \mu \mathrm{m}$; spores abundant, subglobose to globose yellowish brown, thick-walled, IKI-, CB-, $(5.7-) 6-9(-9.3) \times(4.6-) 5-7(-7.3) \mu \mathrm{m}, \mathrm{L}=7.85 \mu \mathrm{m}, \mathrm{W}$ $=6.2 \mu \mathrm{m}, \mathrm{Q}=1.22-1.32,(\mathrm{n}=25 / 2)$.

Specimens examined - INDIA, Tamil Nadu, Coimbatore, Pullachi, on a dead rotting trunk of Ficus, 6 Dec. 2012, J.R. Sharma, JRS 712 (BSD); ibid, Kavai Courtalum, on a dead trunk of Ficus, 7 Dec. 2012, J.R. Sharma, JRS 917 (BSD).

Remarks - This species usually grows on dead and rotting trunks of Ficus and rarely on and other hardwoods. The species is separated on the basis of larger spores, distinct duplex consistency of the context and presence of setal hyphae and hymenial setae. It is closely related to $I$. patouillardii but differs in having the setal hyphae both in the context and the dissepiments, smaller pores and spores. Further, I. patouillardii has a temperate distribution unlike the present species which is confined to tropical areas.

Inonotus porrectus Murr., Tropical Polypores p. 68, 1915

Figs 17,18

Basidiocarps annual, flbelliform or substipitate with a narrowed base, pilei circular to dimidiate, single or imbricate, 20-35 mm wide, up tp $40 \mathrm{~mm}$ broad and 10-30 $\mathrm{mm}$ thick; pilear surface bright yellowish brown, zonate, finely tomentose, margin acute to rounded, concolorous, staining dark brown on bruising and on drying; pore surface dull purplish brown, pores circular to 
angular 5-6 per mm, dissepiments thin, entire tube layer purplish brown, decurrent on the narrowed base, 2-5 mm deep; context golden brown, lustrous, zonate, firm, fibrous brown to dark purplish brown, up to $20 \mathrm{~mm}$ thick.

Hyphal system monomitic, hyphae thin to moderately thick-walled, hyaline to pale yellowish 4-8.5 $\mu \mathrm{m}$ wide, tramal hyphae difficult to separate; hymenial setae absent; basidia broadly clavate, 4-sterigmate, 12-18 x 5-6 $\mu \mathrm{m}$; basidiospores broadly ellipsoid to ovoid, reddish brown, IKI-, CB-, (3.9-)4.5-6(-6.2) ×(3.2-)3.5-4.5(-4.7) $\mu \mathrm{m}, \mathrm{L}=5.6 \mu \mathrm{m}, \mathrm{W}=3.95 \mu \mathrm{m}, \mathrm{Q}=1.38-1.47(\mathrm{n}=25 / 2)$.

Specimens examined- INDIA, Tamil Nadu, Coimbatore, Annakutti, on a fallen hardwood tree trunk, 30 Nov. 2012, J.R. Sharma, JRS 1204 (BSD); ibid, Koller, on fallen trunk of a hardwood tree, 30 Nov. 2012, J.R. Sharma, JRS 1307, 1302 (BSD).

Remarks - The substipitate basidiocarps growing on dead hardwoods, multizonate pilear surface, absence of any setigerous elements and smaller spores, bright golden yellow, lustrous context and darker purplish brown tube layer are the distinguishing characters of this species. The closely related I. tenuicarnis has azonate pilear surface, cinnamon-brown context, larger spores and pores.

Inonotus ryvardenii J.R. Sharma \& D. Mishra, sp. nov.

Figs 1-5, 27, 28 MycoBank - MB 803349

Etymology - Named in honour of Prof. Leif Ryvarden, University of Oslo who has contributed greatly to the knowledge of these fungi.

Basidiocarps annual, pileate, solitary or often imbricate or laterally confluent, sessile, dimidiate to almost ungulate, soft when fresh, corky when dry, broadly attached, forming composite structures, individual pilei 40-50 mm wide, 60-70 mm long and 10-20 mm thick near the base, upper surface coarsely hispid, forming a coarse hispid tomentum composed of fasciculate groups of agglutinated hyphae, up to $3 \mathrm{~mm}$ deep, yellowish brown, becoming dark reddish brown to blackish towards the base, margin obtuse, entire, lighter in colour, slightly curved; pore surface plane to concave, chestnut brown, with a narrow sterile margin, pores 5-6 per $\mathrm{mm}$, round to angular, tubes nonstratose, distinct and lighter than context, yellowish brown, brittle, 8-10 mm deep; context thinner than the tube layer, consisting of two layers not separated by a black line, lower layer dark brown, tough-corky, with a silky sheen, without any white flecks, 2-4 mm thick, upper part soft, forming a tomentum of agglutinated hyphae, 2-6 mm thick.

Hyphal system monomitic, contextual generative hyphae predominantly unbranched, thickwalled, fairly loosely interwoven, 8-10 $\mu \mathrm{m}$ wide, dark brown, these interlaced with narrower, pale brown, fairly branched and contorted hyphae, 3-6 $\mu \mathrm{m}$ wide, hyphae in the tomentum dark thickwalled to solid, wider up to $16 \mu \mathrm{m}$, tramal generative hyphae of one type only agglutinated, parallel thin to firm-walled, frequently septate with occasional branching, pale golden brown, 4-6 $\mu \mathrm{m}$ wide, simple septate; setae and setal hyphae absent; basidia broadly ellipsoid, 4-sterigmate, 12-16 $\times 8-10$ $\mu \mathrm{m}$, simple sptate at the base; spores present abundantly, broadly ellipsoid, hyaline to pale yellowish, smooth, thin to moderately thick-walled, IKI-, CB- (3.9-)4.5-5(-5.4) $\times(2.95-) 3-4(-$ 4.3) $\mu \mathrm{m}, \mathrm{L}=4.77 \mu \mathrm{m}, \mathrm{W}=3.67 \mu \mathrm{m}, \mathrm{Q}=1.24-1.34$, $(\mathrm{n}=25 / 1)$.

Specimens examined - INDIA, Uttarakhand, Nainital, Kaladungi, on base of a rotting stump of Shorea robusta Roxb. ex Geartn.f., 7 Aug. 2010, J.R. Sharma, JRS 15034 (holotype, BSD); ibid., Uttarakhand, Nainital, Kaladungi, on base of a rotting stump of angiosperm tree, 15 Aug. 2011, J.R. Sharma, JRS 12037 (BSD); ibid., Uttarakhand, Dehradun, on fallen wood of Delonix regia (Bojer) Raf., 10 Sept. 2011, J.R. Sharma, JRS 13027 (BSD).

Remarks - Inonotus ryvardenii is characterized by its pileate sporocarps with coarsely hispid pilear surface composed of fasciculated groups of hyphae, double layered context, absence of any setal elements and broadly ellipsoid hyaline to pale yellowish spores. This species may be confused with I. hispidus (Bull.) P. Karst. and I. subhispidus Pegler \& Reid in the characters of pilear surface. But the former has hymenial setae, larger pores (1-3 per $\mathrm{mm}$ ) and thick-walled dark brown larger spores $(8-11 \times 6-8 \mu \mathrm{m})$ while in the latter, the context is permeated with whitish flecks beside larger pores (2-3 per $\mathrm{mm}$ ), persistently dark brown pilear surface, which does not become 


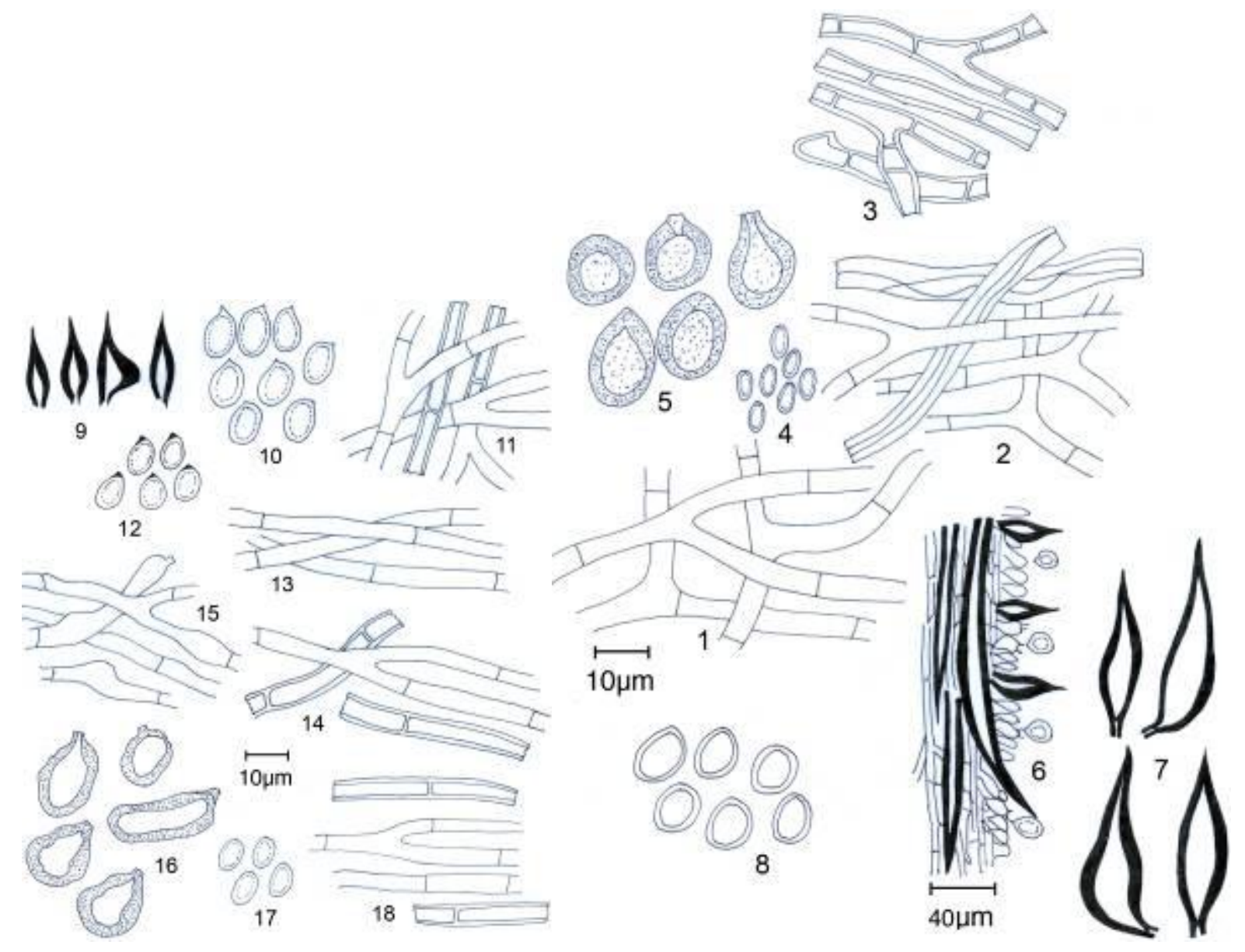

Figs 1-18 - 1-5 - Inonotus ryvardenii (JRS 15034). 1 Tramal hyphae. 2 Contexual hyphae. 3 Hyphae from pilear surface. 4 Spores. 5 Chlamydospores. 6-8 - Inonotus ochroporus (JRS 712). 6 Schematic drawing of hymenium. 7 Hymenial setae. 8 Spores. 9-11 - Inonotus obliquus (JRS 3012) 9 Hymenial setae. 10 Basidiospores. 11 Generative hyphae. 12-16 - Inocutis tamaricis (JRS 509) 12 Spores. 13 Tramal hyphae. 14 Contextual hyphae. 15 Hyaline hyphae from granular core. 16 Fragments of thick-walled hyphae from granular core. 17-18 - Inonotus porrectus (JRS 1204) 17 Spores. 18 Generative hyphae.

black with age, and larger $(7-9 \times 5-6.5 \mu \mathrm{m})$ dark brown spores. I. ungulatus Ryvarden described from Australia also lack setal elements and has similar spore characters but has a black cuticle on the pilear surface and above all a mycelia core in the context. I. mikalodi (Lloyd) Nunez \& Ryvarden known from Japan and Taiwan also lacks setal elements but has larger pores and rusty brown spores and different host characters. Similarly, I. pirisporus Pegler has subglobose piriform spores and different host characters.

Onnia P. Karst., Bidr. Kann. Finl. Nat. Folk 48: 326, 1889

Basidiocarps annual, sessile or stipitate; pilear suface yellowish to rusty brown; tomentose, velutinate to rough; pore suface brown to chestnut brown; context rusty brown, duplex upper layer spongy, lower layer corky; hyphal system monomitic, generative hyphae simple septate; setal hyphae absent; hymenial setae present; cystidia none; spores cylindrical or ellipsoid, thin-walled, hyaline, smooth, IKI-; on living or dead woods of gymnosperms and angiosperms or on ground close to them causing a white rot.

The genus Onnia is homogeneous and is mainly separated on the basis of duplex context and presence of hymenial setae. It resembles Inonotopsis in hyaline and thin-walled spores, but differs in that the former lacks setae while setae are present in the latter. The genus Inonotus has thick- 


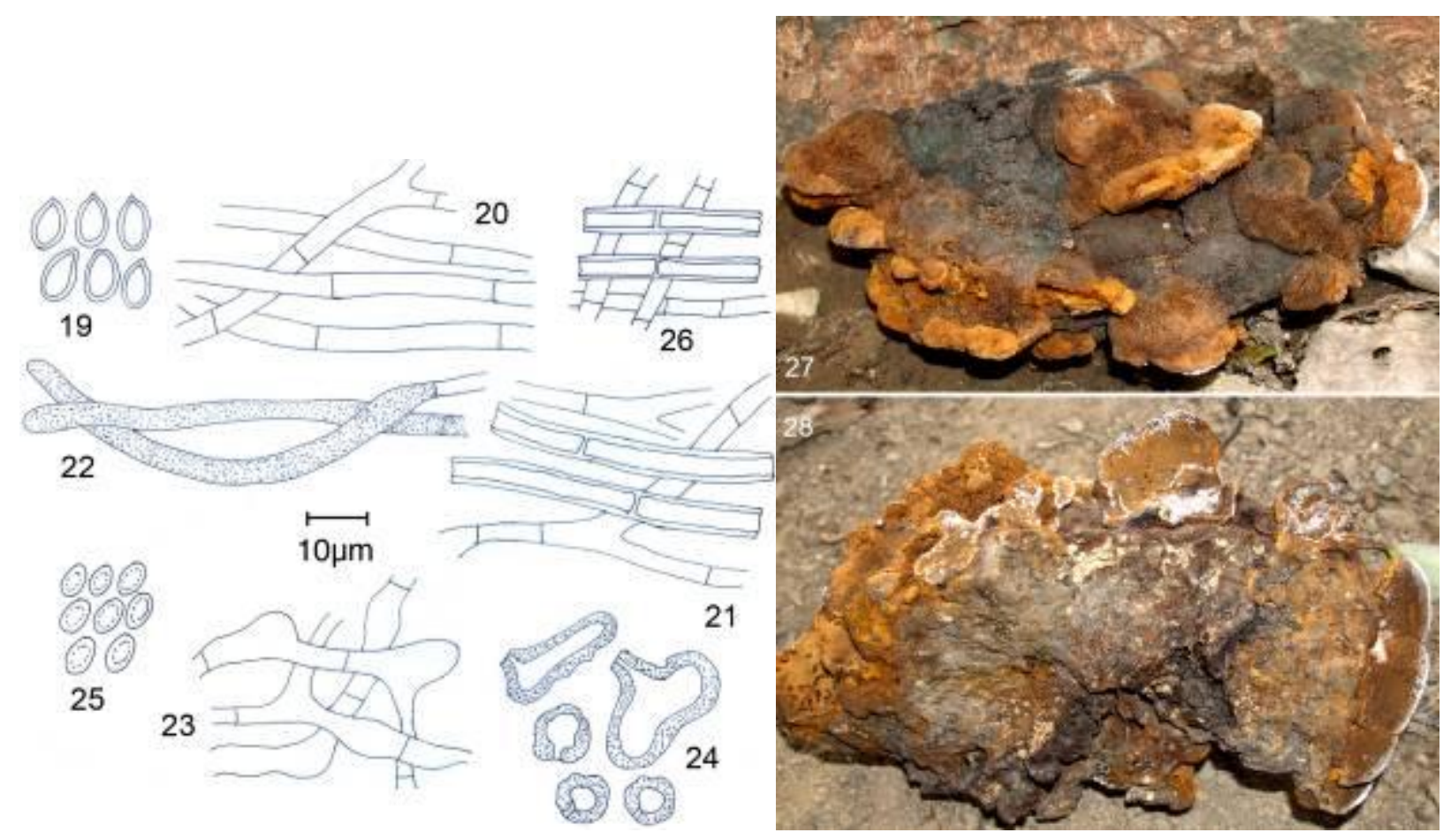

Figs 19-28 - 19-24 Inocutis texanus (JRS 1481). 19 Spores. 20 Tramal hyphae. 21 Contextual hyphae. 22 Gloeopleurous hyphae. 23 Hyaline hyphae from granular core. 24 Fragments of thickwalled hyphae from granular core. 25-26 - Inonotus juniperinus (JRS 1206). 25 Spores. 26 generative hyphae. 27-28 - Basidiocarps of Inonotus ryvardenii (JRS 15034) growing at the base of Shorea robusta tree. 27 Dorsal view. 28 Ventral view.

walled spores while Inocutis has a granular core. In the presence of stipe, the species of Onnia often resemble Coltricia but the presence of hymenial setae in Onnia differentiate them.

Type species: Onnia tomentosa (Fr.) P. Karst.

\section{Provisional key to the Indian species of Onnia}

1. Spores cylindrical O. flavidus

1. Spores ovoid to ellipsoid. .2

2. Basidiocarps usually growing growing singly; hymenial setae hooked. O. circinatus

2. Basidiocarps usually growing in groups; hymenial setae not hooked... .3

3. Hymenial setae 45-65(-70) $\times 7-12 \mu \mathrm{m}$, tips straight; spores $4.5-6 \times 3-4 \mu \mathrm{m}$......... 3. Hymenial setae $27-30(-35) \times 7-9 \mu \mathrm{m}$, tips straight or dichotomously split; spores $5-7 \times 4-6$ $\mu \mathrm{m}$ O. vallata

Pseudoinonotus T. Wagner \& M. Fischer, Mycol. Res. 105(7): 781, 2001

Basidiocarps annual, pileate, pilear surface velutinate to smooth, zonate or azonate, cracking at maturity, context homogeneous; hyphal system monomitic, generative hyphae hyaline to yellowish brown, thin to thick-walled, setal hyphae absent, hymenial setae, hyaline, thick-walled, strongly dextrinoid and cyanophilous, usually on angiosperms causing white rot.

Type species: Pseudoinonotus dryadeus (Pers.) T. Wager \& M. Fischer

The genus Pseudoinonotus has been recently separated from Phellinus robustus complex and is evidently a homogeneous genus in the Hymenochaetaceae. It is mainly separated on the basis of strongly dextrinoid spores and strongly cyanohilous spores. The closely related Fomitiporia has a perennial habit and the presence of cystidioles in the hymenium. 


\section{Provisional key to the Indian species of Pseudoinonotus}

1. Basidiospores 5.5-8 $\times 5-7 \mu \mathrm{m}$; margin obtuse.................................. dryadeus

1. Basidiospores $4.5-5.6 \times 3.5-5 \mu \mathrm{m}$; margin acute............................. brevisporus

\section{Acknowledgements}

The authors are grateful to the Director, Botanical Survey of India, Kolkata (India) for providing facilities during this study.

\section{References}

Dai YC. 1995a - Changbai wood-rotting fungi-3. The genus Phellinidium (Basidiomycetes) and a new species, $P$. aciferum. Ann. Bot. Fennici 32, 63-73.

Dai YC. 1995b - Phellinus sensu lato (Aphyllophorales, Hymenochaetaceae) in East Asia. Acta Botanica Fennica 116, 1-115.

Donk MA. 1933 - Revision der Niederlandischen Homobasidiomycete. Aphyllophoraceae. Meded. Bot. Mus. Herb. Utrecht 9: 1-278.

Fiasson JL. 1982 - Distribution of styrylpyrones in the basidiocarps of various hymenochaetaceae. Biochemical Systematics and Ecology 10(4), 289-296.

Fiasson JL, Niemela T. 1984 - The Hymenochaetales: a revision of the European poroid taxa. Karstenia 24, 14-28.

Fischer M. 1996 - On the species complexes with in Phellinus: Fomitiporia revisited. Mycological Research 100, 1459-1467.

Fischer M, Ainsworth M, Wagner T. 2001 - Phellinus cavicola: a species not assignable to European subgroups of Phellinus s.l. Mycologist 15, 16-18.

Gilbertson RL. 1976 - The genus Inonotus (Aphyllophorales, Hymenochaetaceae) in Arizona. Mem. N.Y. Bot. Gard. 28, 67-85.

Gilbertson RL, Ryvarden L. 1986 - North American Polypores-1, Fungiflora, Oslo. 434 p.

Gilbertson RL, Wright JE, Monclavo, JM. 2002 - Inonotus s.l. in Argentina. Morphology, cultural characters and molecular analyses. Mycological Progress 1, 299-313.

Holmgren PK, Holmgren NH, Barnett LC. 1990 - Index Herbariorum. Part 1: Herbaria of the world, $86^{\text {th }}$ ed. USA, Bronx, New York Botanical Garden.

Imazeki R. 1943 - The genera of polyporaceae of Nippon. Bull. Tokyo Sci. Mus. 6, 111 p.

Niemela T, Wagner T, Fischer M, Dai YC. 2001 - Phellopilus gen. nov. and its affinities within Phellinus sensu lato and Inonotus sensu lato (basidiomycetes). Ann. Bot. Fennici 38, 51-62.

Pegler DN. 1964 - A survey of the genus Inonotus (Polyporaceae). Transactions of the British Mycological Society 47(2), 175-195.

Petersen JH. 1996 - The Danish Mycological Society's color- chart. Foreningen til Swampekundskabens Fremme, Greve. 6.

Rayner RW. 1970 - A mycological colour chart. Commonwealth Mycological Institute, Kew, 9 plates, $34 \mathrm{p}$.

Ryvarden L. 1991 - Genera of polypores. Nomenclature and taxonomy. Fungiflora, Oslo. 363 p.

Ryvarden L. 2005 - The genus Inonotus, a synopsis. Synopsis Fungorum 21, 149 p.

Ryvarden L, Gilbertson RL. 1993 - European Polypores -1. Synopsis Fungorum 6, 387 p.

Sharma JR. 1995 - Hymenochaetaceae of India. Botanical Survey of India, Kolkata. 219 p.

Wagner T, Fischer M. 2001 - Natural groups and a revised system for the European poroid Hymenochaetales (Basidiomycota) supported by nLSU rDNA sequence data. Mycological Research 105, 773-782.

Wagner T, Fischer M. 2002 - Classification and Phylogenetic relationships of Hymenochaete and allied genera of the Hymenochaetales inferred from rDNA sequence data and nuclear behavior of vegetative mycelium. Mycological Progress 1, 93-104.

Wagner T, Ryvarden L. 2002 - Phylogeny and taxonomy of the genus Phylloporia (Hymenochaetales). Mycological Progress 1, 105-116. 